\title{
PENDIDIKAN PEMAKAI DI PERPUSTAKAAN SEBAGAI UPAYA PEMBENTUKAN PEMUSTAKA YANG LITERASI INFORMASI
}

\author{
Roro Isyawati Permata Ganggi*
}

Pengutipan: Permata Ganggi, R. I. (2017). Pendidikan pemakai di perpustakaan sebagai upaya pembentukan pemustaka yang literasi informasi. Khizanah al-Hikmah : Jurnal Ilmu Perpustakaan, Informasi, dan Kearsipan, 5(1), 121-128.

DOI: http://dx.doi.org/10.24252/kah.v5i1a11

\section{*Staf Pengajar di Program Studi Ilmu Perpustakaan Universitas Diponegoro Semarang} isya.ganggi@gmail.com

\begin{abstract}
ABSTRAK
Pesatnya perkembangan teknologi informasi berbanding lurus dengan perkembangan informasi. Perkembangan informasi yang semakin tak terkendali pada akhirnya justru menimbulkan masalah. Banyak informasi sampah dan berita bohong yang beredar di masyarakat. Informasi yang seperti ini harus dihindari supaya masyarakat tidak terkecoh. Literasi informasi merupakan salah satu cara untuk membantu seseorang dalam memilih informasi yang dibutuhkan. Literasi informasi mengajarkan seseorang untuk memilih informasi dengan memperhatikan otoritas dan isi suatu informasi. Kemampuan literasi informasi wajib dimiliki oleh pustakawan sebagai bekal dalam memilih informasi yang akan diadakan di perpustakaan. Kemampuan ini akan lebih baik lagi dapat ditularkan kepada masyarakat supaya dapat menciptakan masyarakat yang literate. Literasi informasi dapat diajarkan kepada masyarakat melalui pendidikan pemakai yang dilakukan oleh perpustakaan.

Kata kunci: Literasi informasi, pendidikan pemakai, masyarakat literat

\section{ABSTRACT}

The rapid development of information technologies is directly proportional to the development of information. The uncontrolled information ultimately causes problems. A lot of spam information and hoax news are spread in the community. Information like this should be avoided so that the public do not be fooled. Information literacy is one way to help a person in choosing the needed information. Information literacy teaches a person to choose an information that needed having regard to the authority of information and content of the information. Mandatory information literacy ability possessed by the librarian as a provision in selecting the information to be held in the library. This ability would be better yet if it can be transmitted to the community in order to create a literate society. Information literacy can be taught to the community through user education carried out by the library.
\end{abstract}

Key words: Information literacy, user education, literate society

\section{PENDAHULUAN}

Perkembangan teknologi informasi yang pesat secara langsung berdampak pada perkembangan informasi, bersamaan dengan semakin mudahnya informasi dibuat, maka keterkinian informasi menjadi hal yang sulit diikuti. Infomasi yang baru saat ini akan menjadi out of date dalam kurun waktu yang relatif 
cepat. Informasi yang sudah out of date akan tetap ada dalam database informasi, sehingga memungkinkan tercampurnya informasi baru dan informasi yang lama. Selain kekinian informasi, otoritas suatu informasi juga merupakan hal penting yang patut dipertanyakan. Karena banyaknya orang yang membuat informasi mengharuskan kita lebih jeli untuk mengenali mana informasi yang terpercaya, mana informasi sampah (spam) dan mana berita bohong (hoax). Ada banyak jumlah informasi yang beredar sering disebut sebagai ledakan informasi, karena jumlahnya yang tak dapat dikendalikan lagi.

Perlu adanya keterampilan dalam mencari, menemukan dan memilih informasi yang tepat sesuai kebutuhan. Keterampilan pemecahan masalah yang berhubungan dengan pencarian informasi dikenal sebagai literasi informasi atau melek informasi. Literasi informasi merupakan keterampilan penunjang dalam pembelajaran sepanjang hayat. Utamanya lagi keterampilan ini dapat membantu seseorang mencari informasi yang tepat dan sesuai secara efektif dan efisien di belantara informasi. Dalam dunia perpustakaan literasi informasi merupakan keterampilan wajib yang harus dimiliki pustakawan dalam rangka menyeleksi informasi yang ada di perpustakaannya. Perpustakaan sendiri merupakan lembaga penunjang pembelajaran sepanjang hayat, maka dari itu kemampuan literasi informasi yang dimiliki oleh pustakawan perlu kiranya ditularkan kepada para pemustaka.

\section{KAJIAN PUSTAKA}

\section{a. Pendidikan Pemakai}

Pendidikan pemakai atau user education oleh Hazel Mews (1972, 7) didefinisikan sebagai pemberian intruksi pada pengguna perpustakaan untuk menolong mereka menjadi pengguna yang baik. Sedangkan menurut Renford and Hendrickson $(1980,84)$ pendidikan pemakai adalah suatu kegiatan pengajaran dengan menggunakan berbagai sumber perpustakaan dan caracara penelitian. Definisi pendidikan pemakai menurut Soedibyo (1987, 121) adalah sebagai berikut: Pendidikan pemakai adalah usaha bimbingan atau penunjang pada pemakai tentang cara pemanfaatan koleksi bahan pustaka yang disediakan secara efektif dan efesien, bimbingan itu dapat berupa bimbingan individu ataupun secara kelompok. Pendidikan pemakai oleh penulis diterjemahkan sebagai pemberian instruksi atau bimbingan pada user agar dapat menggunakan sumber daya di perpustakaan secara maksimal, baik berupa bimbingan individu ataupun kelompok.

\section{b. Tujuan Pendidikan Pemakai}

Pendidikan pemakai memiliki tujuan yang ditetapkan secara objektif. Dalam hal ini, perpustakaan harus dapat mengidentifikasi berbagai sasaran yang ingin dicapai didasarkan atas prioritas pada porsinya masing-masing. Oleh sebab itu, penerapan pendidikan pemakai pada perpustakaan harus diiringi dengan berbagai target yang ingin dicapai. Secara umum tujuan diadakannya pendidikan pemakai tercantum dalam Perpustakaan Perguruan Tinggi: Buku Pedoman (2004, 95) sebagai berikut:

1) Meningkatkan keterampilan pengguna agar mampu memanfaatkan kemudahan dan sumber daya perpustakaan secara mandiri.

2) Membekali pengguna dengan teknik yang memadai dan sesuai untuk menemukan informasi dalam subjek tertentu. 
3) Meningkatkan pemanfaatan sumber daya dan layanan perpustakaan.

4) Mempromosikan layanan perpustakaan.

5) Menyiapkan pengguna agar dapat mengantisipasi perkembangan ilmu dan teknologi.

Sulistyo-Basuki

(2004,

menyatakan bahwa tujuan pendidikan pemakai adalah sebagai berikut: Mengembangkan keterampilan pemakai yang diperlukannya untuk menggunakan perpustakaan atau pusat dokumentasi, mengembangkan keterampilan tersebut untuk mengidentifikasi masalah informasi yang dihadapi pemakai, merumuskan kebutuhan informasinya sendiri (pemakai), mengidentifikasi kisaran kemungkinan sumber informasi yang tersedia untuk memenuhi kebutuhannya, menilai ketepatan, kekuatan dan kelemahan masing-masing sumber informasi dan yang paling penting mampu menghadapi ketidaksamaan informasi yang disediakan oleh sumber yang berlainan dan mengasimilasi, mengumpulkan, menyajikan dan menerapkan informasi.

Berdasarkan beberapa pendapat tersebut, maka dapat diketahui bahwa tujuan diadakannya pendidikan pemakai pada perpustakaan terutama untuk meningkatkan minat dan keterampilan pengguna sehingga dengan demikian pengguna perpustakaan akan menyadari arti penting memanfaatkan perpustakaan dengan lebih secara lebih maksimal, yang artinya pengguna diharapkan memiliki sifat kritis terhadap segala informasi yang diserap serta mampu menilai secara objektif informasi tersebut sehingga dapat lebih selektif menerapkan jenis informasi ke dalam kehidupannya.
Konsep awal literasi informasi lahir di Amerika Serikat dan dicetuskan oleh Paul Zurkowski, Presiden US Information Industry Association, pada tahun 1974 dalam proposal yang disampaikan dalam The National Commission on Libraries and Information Science (NCLIS), bahwa dalam program nasional salah satu yang harus dicapai adalah literasi informasi secara universal. Zurkowski yang mengatakan:

"Seseorang yang terlatih dalam mengaplikasikan sumber informasi dalam menyelesaikan pekerjaan mereka dapat disebut orang yang melek informasi. Mereka telah mempelajari teknik dan keterampilan untuk keperluan dalam area luas dari beragam alat informasi seperti sumber primer dalam pembentukan informasi untuk mendapat solusi masalah mereka" (Manchester Metropolitan University, 1).

International Federation of Library Associations and Institutions (IFLA) menerangkan agar literasi informasi, seseorang harus dapat menyadari ketika informasi diperlukan dan dibutuhkan untuk melokasi dan mengevaluasi, dan menggunakan secara efektif informasi tersebut (IFLA, 2004, 2). Literasi informasi yang digunakan adalah kemampuan seseorang untuk mencari, menemukan, menganalisis dan mengevaluasi suatu informasi dari berbagai macam sumber informasi yang ada sesuai dengan kebutuhannya.

\section{d. Tujuan Literasi Informasi}

Dalam dunia pendidikan perguruan tinggi literasi informasi dibagi menjadi dua tujuan, seperti yang dijelaskan pada laporan hasil Seminar FPPTI Jabar-Banten mengenai Literasi Informasi dan Plagiarisme (2011) yaitu:

\section{c. Literasi Informasi}


1) Umum (lifelong learning)

a) Berfikir kritis

b) Mengevaluasi informasi di tengah le dakan informasi.

c) Penggunaan informasi efisien dan efektif yang relevan secara etis dan legal serta menghindari plagiarism.

2) Khusus

a) Profesionalisme sumber daya manusi a (SDM).

b) Meningkatkan kualitas dan kuantitas karya ilmiah civitas akademika.

c) Mengantarkan perguruan tinggi men jadi World Class University.

d) Meningkatkan daya belajar mahasiswa sehingga lebih siap menghadapi dunia perkualiahan.

e) WEBOMETRIC, dengan berjalannya literasi informasi, webometric akan $n$ aik

\section{e. Perbedaan Literasi Informasi dengan Pendidikan pemakai}

Pendidikan pemakai dan istilah lain seperti library instruction, bibliographic instruction, telah menyumbangkan konsep bagi literasi informasi. Jika pendidikan pemakai adalah melatih pemakai bagaimana menggunakan perpustakaan dan koleksinya maka literasi informasi berfokus pada strategi dan proses pencarian informasi serta kompetensi penggunaan informasi (Lau, 2006). Literasi informasi mencakup hal yang lebih luas dan tidak terbatas hanya pada informasi yang terdapat di perpustakaan saja tetapi juga di luar perpustakaan (Wooliscroft, 1997). Jika digambarkan melalui tabel maka akan didapat data seperti berikut:
Tabel 1. Perbedaan Pendidikan Pemakai dengan Literasi Informasi

\begin{tabular}{|l|l|}
\hline \multicolumn{1}{|c|}{ Pendidikan pemakai } & \multicolumn{1}{|c|}{ Literasi Informasi } \\
\hline $\begin{array}{l}\text { Meliputi penggunaan } \\
\text { alat riset yang ada atau } \\
\text { dapat diakses melalui } \\
\text { perpustakaan. }\end{array}$ & $\begin{array}{l}\text { Fokus pada proses berpikir } \\
\text { kritis pada kemampuan } \\
\text { lain penggunaan informasi } \\
\text { yang menunjang } \\
\text { pembelajaran sepanjang } \\
\text { hayat. }\end{array}$ \\
\hline $\begin{array}{l}\text { Dikontrol sepenuhnya } \\
\text { oleh pustakawan dan } \\
\text { dipusatkan pada } \\
\text { penggunaan } \\
\text { perpustakaan. }\end{array}$ & $\begin{array}{l}\text { Desain kolaboratif, } \\
\text { pengiriman dan penilaian } \\
\text { instruksi oleh pustakawan } \\
\text { atau instruktor. }\end{array}$ \\
\hline $\begin{array}{l}\text { Tidak sepenuhnya } \\
\text { dihubungkan dengan } \\
\text { kurikulum atau kelas } \\
\text { seseorang. }\end{array}$ & $\begin{array}{l}\text { Dilengkapi dan } \\
\text { diintegrasikan kedalam } \\
\text { kelas atau kurikulum. }\end{array}$ \\
\hline $\begin{array}{l}\text { Metode } \\
\text { pembelajarannya } \\
\text { melibatkan } \\
\text { perkuliahan, } \\
\text { demonstrasi, atau } \\
\text { penekanan pada } \\
\text { presenter. }\end{array}$ & $\begin{array}{l}\text { Metode pembelajarannya } \\
\text { melibatkan pembuatan } \\
\text { lingkungan pembelajaran } \\
\text { dimana pustakawan dan } \\
\text { dosen berfungsi sebagai } \\
\text { pembimbing atau } \\
\text { pemandu. }\end{array}$ \\
\hline
\end{tabular}

\section{PEMBAHASAN LITERATUR}

Pendidikan pemakai merupakan suatu agenda wajib bagi mahasiswa tahun ajaran baru di suatu universitas. Program ini dilaksanakan dengan berbagai metode yaitu ceramah di dalam kelas, tour dalam perpustakaan, game, dan post-test atau pre test. Pendidikan pemakai kebanyakan di selenggarakan oleh perpustakaan perguruan tinggi karena sumber daya perpustakaan yang dimiliki lebih kompleks dan beragam, selain itu jumlah pemustaka lebih banyak.

Pendidikan pemakai biasanya diselenggarakan setahun sekali pada saat tahun ajaran baru dengan sasaran mahasiswa baru suatu perguruan tinggi. Materi yang diajarkan pada pendidikan pemakai terbatas pada penggunaan koleksi atau peralatan yang ada di perpustakaan saja. Metode yang paling 
sering digunakan adalah ceramah atau tour dalam perpustakaan. Pustakawan memberikan ceramah pada pemustaka baru di dalam ruang kelas dengan menggunakan slide presentasi. Pustakawan bisa juga membawa pemustaka berkeliling ke perpustakaan dan menjelaskan bagian-bagian perpustakaan, bagaimana cara menggunakan koleksi dan peralatan, bagaimana cara meminjam dan mengembalikan. Pemustaka akan diberikan waktu untuk mencoba sendiri layanan dan bagaimana memanfaatkan sumber daya perpustakaan.

Pendidikan pemakai dapat juga digunakann sebagai sarana promosi suatu perpustakaan. Saat pendidikan pemakai dilakukan pemustaka baru akan lebih mengenal perpustakaan. Jika pemustaka dapat mengenal perpustakaan lebih dekat maka diharapkan pemustaka akan tertarik dan akhirnya akan melaksanakan oral promosi. Hal ini tentu saja akan lebih menghemat biaya dan akan lebih efektif. Tidak mengherankan jika pada saat kegiatan pendidikan pemakai perpustakaan memberikan cinderamata. Tujuan pemberian cinderamata tersebut adalah untuk ajang promosi, pengenalan nama dan logo perpustakaan.

Analisis tujuan diadakannya pendidikan pemakai dengan tujuan literasi informasi di perpustakaan perguruan tinggi perlu diketahui untuk melihat hubungan antara keduanya. Fungsi tersebut diambil dari Perpustakaan Perguruan Tinggi: Buku Pedoman (2004, 95). Pendidikan pemakai bertujuan untu membekali pengguna dengan teknik yang memadai dan sesuai untuk menemukan informasi dalam subjek tertentu. hal ini senada dengan definisi literasi informasi.
Berdasarkan definisi literasi, dibutuhkan teknik dan kemampuan untuk menggunakan alat informasi dan sumber primer tentunya hal ini akan dapat diperoleh dari kegiatan pendidikan pemakai. Sehingga, seharusnya pustakawan dalam hal ini perlu adanya mengajarkan juga bagaimana teknik mencari informasi di dunia maya dan tidak terbatas hanya pada sumber informasi yang dimiliki perpustakaan saja.

Pendidikan pemakai berfungsi untuk meningkatkan pemanfaatan sumber daya dan layanan perpustakaan. Sering disinggung bahwa literasi informasi merupakan bekal pendidikan sepanjang hayat. Jika pendidikan pemakai dikombinasikan dengan benar maka diharapkan perpustakaan benar-benar menjadi salah satu lembaga penunjang pendidikan sepanjang hayat yang dimaksud. Sehingga, hal itu tentu akan menguntungkan perpustakaan karena statistik minat kunjung masyarakat yang tinggi ke perpustakaan.

Literasi informasi juga dapat menjadi ajang mempromosikan layanan perpustakaan. Literasi informasi membuat seseorang dapat mencari dan menemukan sumber informasi yang cepat ditempat yang benar. Hal ini akan membuat perpustakaan menjadi lebih populer dalam hal penemuan sumber informasi yang relevan. Kita tahu bahwa saat ini internet merupakan media paling populer dalam hal pencarian informasi karena kecepatan dan aksesnya yang mudah. Tetapi dengan penciptaan pemustaka yang literasi informasi dari kegiatan pendidikan pemakai maka akan mungkin jika internet dapat digunakan sebagai katalog dan perpustakaan tetap menjadi 
media utama dalam menemukan informasi primer.

Menyiapkan pengguna agar dapat mengantisipasi perkembangan ilmu dan teknologi merupakan salah satu tujuan pendidikan pemakai. Adanya ledakan informasi dan pembaharuan teknologi yang berkembang begitu cepat membuat seseorang harus senantiasa memperbarui pengetahuannya. Banyak informasi yang tersebar baik dalam bentuk cetak maupun non cetak, dengan pengajaran pendidikan pemakai dalam basis literasi informasi.

Pedidikan pemakai saat ini seharusnya tidak hanya terbatas pada pemberian instruksi untuk sumber daya di dalam perpustakaan saja, tetapi sudah saatnya pendidikan pemakai diperluas juga dalam penggunaan bahan lain di luar perpustakaan. Pemberian instruksi dalam penggunaan internet secara tepat dan aman juga dapat dimasukkan dalam kurikulum pendidikan pemakai perpustakaan.

Waktu pelaksanaan pendidikan pemakai pun seharusnya tidak hanya dilakukan sekali ketika menjadi pemustaka baru. Pemberian pendidikan pemakai yang hanya dilakukan sekali kemungkinan akan membuat seseorang cepat lupa dan ketika ada teknologi atau sumber informasi baru yang ada di perpustakaan maka pemustaka tidak dapat menggunakannya secara optimal. Perlu adanya up date pendidikan pemakai sehingga pemustaka dapat mengikuti juga perubahan yang terjadi di perpustakaan. Frekuensi pemberian pendidikan pemakai pun harus difikirkan dengan matang karena jika terlalu sering maka kemungkinan pemustaka akan cepat bosan.

Setiap perpustakaan memiliki pemustaka yang memiliki karakteristik yang berbeda-beda. Perbedaan karakteristik pemakai di setiap perpustakaan membuat metode pemberian pendidikan pemakai pun berbeda untuk masing-masing perpustakaan. metode pendidikan pemakai penting dipertimbangkan mengingat hal ini erat kaitannya dengan bagaimana pemustaka akan menggunakan perpustakaan pada nantinya.

Integrasi pendidikan pemakai dengan literasi informasi akan membuat pemustaka menggunakan informasi secara beretika. Dengan adanya etika dalam penggunaan informasi maka plagirisme akan dapat dihindari. Sehingga akan banyak manfaat yang didapatkan dari integrasi pendidikan pemakai dengan literasi informasi.

Uraian di atas merupakan tujuan diadakannya pendidikan pemakai berdasarkan Pedoman Penyelenggaraan Perpustakaan Perguruan Tinggi. Sedangkan berdasarkan tujuan diadakannya pendidikan pemakai menurut Sulistyo-Basuki (2004, 392) adalah mengembangkan keterampilan pemakai yang diperlukannya untuk menggunakan perpustakaan atau pusat dokumentasi, mengembangkan keterampilan tersebut untuk mengidentifikasi masalah informasi yang dihadapi pemakai, merumuskan kebutuhan informasinya sendiri (pemakai), mengidentifikasi kisaran kemungkinan sumber informasi yang tersedia untuk memenuhi kebutuhannya, menilai ketepatan, kekuatan dan kelemahan masing-masing sumber informasi dan yang paling penting mampu menghadapi ketidaksamaan informasi yang disediakan oleh sumber yang berlainan dan mengasimilasi, 
mengumpulkan, menyajikan dan menerapkan informasi.

Berdasarkan tujuan di atas maka kita dapat melihat bahwa pendidikan pemakai tidak hanya dibatasi dalam lingkup perpustakaan saja, tetapi dapat diperluas lagi cakupan tujuannya. Uraian SulistyoBasuki tentang tujuan diadakannya pendidikan pemakai sangat dekat kaitannya jika disandingkan dengan definisi literasi informasi, sebagai berikut: kemampuan seseorang untuk mencari, menemukan, menganalisis dan mengevaluasi suatu informasi dari berbagai macam sumber informasi yang ada sesuai dengan kebutuhannya. Kedekatan antara tujuan diadakannya pendidikan pemakai oleh Sulistyo-Basuki dengan definisi literasi informasi, membuat pendidikan pemakai sangat mungkin untuk diintegrasikan dengan literasi informasi.

Pada hasil Seminar FPPTI Jabar-Banten mengenai Literasi Informasi dan Plagiarisme (2011) dijabarkan mengenai tujuan literasi informasi. Jika dikaji lebih dalam maka tujuan umum literasi informasi yang diimplementasikan dalam pendidikan pemakai akan membuat pemustaka menjadi pemustaka yang dapat memanfaatkan informasi secara beretika. Pemustaka yang sadar akan etika memanfaatkan informasi merupakan cara paling efektif untuk menghindari plagiarisme. Hal ini terjadi karena pemustaka yang literat akan menggunakan informasi secara legal, jika harus mengutip maka ia akan membuat kutipan yang sesuai.

Selain itu pemustaka akan digiring untuk berfikir kritis dan kreatif dalam penggunaan informasi. berfikir kritis mengacu pada cara seseorang untuk terus bertanya sehingga akan terjadi adanya pembelajaran seumur hidup. Adanya pemustaka yang terus melakukan pembelajaran seumur hidup tentu akan membuat pemustaka lebih kreatif. Pemustaka yang kreatif menghasilkan banyak ide-ide baru yang dapat memberikan sumbangan dalam ilmu pengetahuan, dan karena ide tersebut berasal dari informasi yang legal maka pemustaka akan lebih percaya diri dalam mempublikasikan karyanya. Hal ini akan memacu adanya pembaharuan dan perkembangan dalam dunia pendidikan, sehingga dunia pendidikan akan lebih dinamis.

Tujuan khusus literasi informasi seperti yang dijabarkan pada Seminar FPPTI Jabar-Banten lebih mengacu pada literasi informasi yang ada di perguruan tinggi, tetapi tidak menutup kemungkinan bahwa hal tersebut dapat diimplementasikan secara umum. Adanya pemustaka yang literate tentu akan meningkatkan profesionalisme seseorang, karena ia menyadari akan kebutuhan informasinya dan ia dapat menemukan media pemenuhan kebutuhan informasi secara tepat.

Pemustaka yang literate akan menyadari pentingnya menyebarkan hasil pencarian informasinya sebagai bentuk kontribusi untuk perkembangan ilmu pengetahuan. Adanya pemustaka literate tentu akan meningkatkan budaya baca dan menulis yang berarti akan membuat perpustakaan makin kaya akan informasi bermanfaat yang dapat dipertanggungjawabkan. Kesadaran seseorang dalam mempublikasikan karyanya akan berimbas pada peningkatan kualitas institusi tempat seseorang bernaung baik institusi akademik maupun non-akademik. 
Pendidikan pemakai yang diintegrasikan dengan literasi informasi diharapkan mampu merubah paradigma masyarakat tentang perpustakaan. Dimana perpustakaan tidak hanya sebagai tempat menyimpan buku tetapi menjadi salah satu sarana mendapatkan informasi yang terpercaya. Perubahan paradigma dapat terjadi jika perpustakaan dirasakan memiliki sumbangan nyata terhadap masyarakat. Sumbangan yang dimaksudkan adalah dengan adanya pendidikan pemakai maka diharapkan pemustaka menjadi pemustaka yang literate.

\section{KESIMPULAN}

Pendidikan pemakai merupakan media pengenalan sumber daya yang dimiliki perpustakaan kepada para penggunanya. Pendidikan pemakai yang diintegrasikan dengan literasi informasi akan membuat pemustaka lebih cerdas dalam memilah dan memilih sumber informasi yang tepat. Pemustaka yang cerdas tentunya akan memberikan banyak kontribusi bagi perpustakaan. Kontribusi itu dapat berupa kritik atau saran dan promosi perpustakaan itu sendiri. Sudah saatnya perpustakaan membuka diri sebagai lembaga utama pengajaran literasi informasi. Jika hal itu dilakukan maka perpustakaan benar-benar akan memberikan kontribusi nyata di masyarakat.

\section{DAFTAR PUSTAKA}

Bundy, A. (2004). "Australian and New Zealand Information Literacy Framework:principles, standards and practice".Adelaide: Australian and New ZealandInstitute for Information Literacy. Dalam http://www.literacyhub.org/docu ments/InfoLiteracyFramework.pdf, diakses tanggal 18 Desember 2012 pukul 12.30 WIB.

Darmono. (2001). Manajemen dan Tata Kerja Perpustakaan Sekolah. Jakarta: Gramedia Widiasarana Indonesia.

Depdiknas. (2004). Perpustakaan Perguruan Tinggi: Buku Pedoman. Jakarta : Departemen Pendidikan Nasional RI Direktorat Jenderal Pendidikan Tinggi.

Eisenberg, M. B, dkk. (2004). Information Literacy:Essential Skills for theInformation Age. London: Libraries Unlimited.

IFLA. 2004. "World Library and Information Congress: 70th IFLA General Conference and Council". Dalam http:/ / archive.ifla.org/IV/ifla70/p apers/059e-Campbell.pdf, tanggal 19 Desember 2011, pukul 19:43.

Manchester Metropolitan University. "Information Literacy: A Literature Review". Dalam http://www.learnhigher.mmu.ac.u $\mathrm{k} /$ research/InfoLit-LiteratureReview.pdf, tanggal 20 Desember 2013, pukul 05:12.

Mews, H. (1972). Reader Instruction in Colleges and Universities. London : The Library Association.

Sekolah Tinggi Seni Rupa dan Desain Indonesia Telkom. 2011. Laporan hasil Seminar FPPTI Jabar-Banten mengenai Literasi Informasi dan Plagiarisme. Dalam http://library.stisitelkom.ac.id/upl oad/document/pdf/latestnews/Seminar_FPPTI_Jabar_dan_B anten.pdf diakses pada tanggal 21 Desember 2013 pukul 12:54.

Soedibyo, N. (1987). Pengelolaan Perpustakaan Jilid 1. Bandung: Alumni.

Sudarsono, B. (2007). Literasi Informasi (Information Literacy): Pengantar untuk Perpustakaan Sekolah. Jakarta: Perpustakaan Nasional RI. 